\title{
PENGARUH PROSEDUR KERJA DAN FASILITAS KERJA TERHADAP EFEKTIVITAS KERJA PEGAWAI DINAS SOSIAL, PEMBERDAYAAN PEREMPUAN DAN PERLINDUNGAN ANAK KABUPATEN PIDIE JAYA
}

\author{
Herizal $^{(1)}$, Mutia ${ }^{(2)}$ \\ ${ }^{1,2}$ Program Studi Manajemen, Universitas Jabal Ghafur, Sigli \\ e-mail : herizal@unigha.ac.id, Fakhrul@unigha.ac.id
}

\begin{abstract}
ABSTRAK
Penelitian ini bertujuan untuk mengetahui pengaruh prosedur kerja dan fasilitas kerja terhadap efektivitas kerja pegawai. Responden dalam penelitian ini sejumlah 32 orang pegawai, data diperoleh melalui pengajuan kuesioner, analisis data menggunakan regresi linier berganda. Hasil penelitian diperoleh bahwa, nilai koefisien kolerasi diperoleh sebesar 95\% dapat memberikan pengertian ada hubungan antara factor prosedur kerja dan fasilitas kerja dengan efektivitas kerja pegawai. Semakin tingginya nilai koefisien korelasi yang diperoleh maka semakin erat pula hubungan antara variable independen dengan variable dependen.

Sedangkan nilai koefisien diterminasi $\left(\mathrm{R}^{2}\right)$ adalah bertujuan untuk mengetahui pengaruh antara prosedur kerja dan fasilitas kerja dengan efektivitas kerja pegawai. Nilai koefisien diterminasi diperoleh sebesar 90,3\% dapat memberikan pengertian ada pengaruh yang signifikan antara factor prosedur kerja dan fasilitas kerja dengan efektifitas kerja pegawai. Dengan demikian dapat dijelaskan bahwa pengaruh prosedur kerja dan fasilitas kerja sebesar $90.3 \%$ berpengaruh secara siginifikan (sig 0,000) terhadap efektivitas kerja pegawai, sedangkan selebihnya 9,7\% dipengaruhi oleh persamaan lain di luar penelitian ini. Ada pengaruh yang signifikan antara prosedur kerja dan fasilitas kerja dengan efektivitas kerja pegawai, dengan demikian keputusan penelitian ini adalah menerima hipotesis Ha. Dapat diambil keputusan bahwa, Uji-T dan Uji-F diperoleh nilai lebih besar dari $\mathrm{T}_{\text {-tabel }}$ dan $\mathrm{F}_{\text {-tabel }}$, sehingga dalam penelitian ini diterima hipotesis Ha dan menolak hipotesis Ho.
\end{abstract}

Kata Kunci: Prosedur Kerja, Fasilitas Kerjadan Efektivitas Kerja

\section{Pendahuluan}

Pegawai sebagai bagian dari sumber daya manusia yang diarahkan pada peningkatan harkat martabat dan kemampuan manusia serta kepercayaan pada diri sendiri dan patuh terhadap peraturan yang telah ditetapkan oleh organisasi tempat pengabdiannya. Oleh karena itu pembagian tugas-tugas dalam organisasi perlu jelas dan baik agar pegawai dalam melaksanakan tugas lebih terarah, dengan terarahnya pelimpahan tugas kepada pegawai, maka tugas-tugas dalam organsiasi dapat diselesaikan sesuai dengan harapan, yang pada akhirnya tujuan organisasi dapat dicapai sebagaimana yang direncanakan.
Peranan individu dalam suatu organisasi sangat besar, artinya peran individu sangat diperlukan dalam melaksanakan tugas-tugas yang dilimpahkan kepadanya dan dapat bertanggungjawab penuh, sehingga sesuatu yang menjadi tugasnya dapat diselesaikan dengan baik.

Keberhasilan suatu organisasi dalam meningkatkan prestasi kerja pegawai adalah melalui semangat kerja yang tinggi, hal ini tergambar dari semangat kerja pegawai dalam organisasi. Kinerja pegawai ditunjang oleh beberapa factor seperti meningkatkan kompetensi dengan baik. Kompetensi merupakan perpaduan dari pengetahuan, keterampilan, nilai dan sikap yang direfleksikan dalam kebiasaan berfikir dan 
bertindak. Pegawai yang berkompetensi dengan baik, mampu melakukan tindakan intelegensi penuh tanggungjawab yang harus dimiliki seseorang sebagai syarat untuk dianggap mampu melaksankan tugastugas dalam organisasi. Sifat tanggungjawab harus ditunjukkan sebagai kebenaran tindakan baik dipandang dari sudut ilmu pengetahuan, teknologi maupun etika. Kompetensi juga merupakan kemampuan atau kecakapan dalam upaya meningkatkan kinerja dengan maksimal.

Keberhasilan organisasi dalam mencapai tujuannya tidak dapat melepaskan diri dari perlunya penetapan prosedur kerja. Karena dengan adanya prosedur kerja, pegawai lebih mudah dalam melaksanakan pekerjaannya dengan mengikuti sistem dan langkah-langkah kerja yang telah ditetapkan. Kelancaran kerja perlu ditunjang oleh adanya fasilitas kerja yang memadai dan sesuai dengan kebutuhan kerja. Dengan tersedianya fasilitas kerja yang mencukupi maka sangat membantu pegawai dalam melancarkan tugas-tugas kerja. Faktor fasilitas kerja merupakan salah satu faktor yang sangat penting yang perlu dimaksimalkan dalam organisasi yang tujuannya untuk mencegah terjadinya kendala yang diakibatkan oleh kurangnya fasilitas kerja yang tersedia.

Pembagian kerja yang tepat supaya setiap pegawai bias melaksanakan tugastugasnya secara efektif. Pengukuran efektivitas kerja didasarkan atas banyaknya tugas yang dipikul dan jumlah pegawai yang melaksanakan tugas tersebut, sehingga dari kedua hal tersebut dapat disusun sesuai dengan kebutuhan organisasi sehingga menghasilkan efektivitas kerja sebagaimana diharapkan.

Pengukuran efektivitas kerja berdasarkan banyaknya tugas yang dipikul dan jumlah pegawai yang melaksanakan tugas tersebut dapat berarti bahwa bila tugas yang dibebankan kepada pegawai sedikit, sementara jumlah pegawai yang melaksanakan tugas tersebut lebih banyak, namun tugas yang dilaksanakan selama ini belum maksimal disebabkan oleh pembagian tugas yang kurang jelas.

Permasalahan yang terjadi selama ini adalah belum ditetapkan suatu prosedur kerja yang jelas dan minimnya fasilitas kerja seperti kursi kerja, meja kerja, komputer, laptop, printer, kenderaan dinas (roda dua) dan ruang kerja yang nyaman untuk penunjang kerja pegawai juga menjadi permasalahan utama. Jika faktor-faktor tersebut di atas diabaikan maka dikhawatirkan tingkat efektivitas kerja pegawai semakin rendah.

\section{Tujuan Penelitian}

Adapun yang menjadi tujuan dalam penelitian ini adalah:

1. Untuk mengetahui pengaruh prosedur kerja terhadap efektivitas kerja pegawai Dinas Sosial, Pemberdayaan Perempuan dan Perlindungan Anak Kabupaten Pidie Jaya.

2. Untuk mengetahui pengaruh fasilitas kerja terhadap efektivitas kerja pegawai Dinas Sosial, Pemberdayaan Perempuan dan Perlindungan Anak Kabupaten Pidie Jaya.

3. Untuk mengetahui pengaruh prosedur kerja dan fasilitas kerja berpengaruh terhadap efektivitas kerja pegawai Dinas Sosial, Pemberdayaan Perempuan dan Perlindungan Anak Kabupaten Pidie Jaya

\section{Tinjauan Pustaka}

Pengertian Prosedur

$$
\text { Menurut Mulyadi (2011:5) }
$$

mendefinisikan: Prosedur adalah suatu urutan kegiatan klerikal, biasanya melibatkan beberapa orang dalam suatu departemen atau lebih yang dibuat untuk menjamin penanganan secara seragam transaksi perusahaan yang terjadi berulangulang. Didalam suatu sistem, biasanya terdiri dari beberapa prosedur dimana prosedur-prosedur itu saling terkait dan saling mempengaruhi. Akibatnya jika terjadi 
perubahan salah satu prosedur, maka akan mempengaruhi prosedur-prosedur yang lain.

Menurut Baridwan (2010:31)

"Prosedur merupakan urutan pekerjaan yang melibatkan beberapa orang dalam suatu bagian atau lebih, disusun untuk menjamin adanya perlakuan yang seragam terhadap transaksi yang sering terjadi”.

Menurut Richard (2011:197) mendefinisikan: "Suatu prosedur adalah suatu urut-urutan kegiatan kerja, biasanya melibatkan beberapa orang di dalam satu departemen atau lebih, yang diterapkan untuk menjamin penanganan yang seragam dari transaksi-transaksi bisnis yang terjadi”. Widjaja (2012:83) mengemukakan“ Prosedur adalah sekumpulan bagian yang saling berkaitan, misalnya: orang, jaringan gudang yang harus dilayani dengan cara tertentu oleh sejumlah pabrik dan pada gilirannya akan mengirimkan pelanggan menurut proses tertentu".

\section{Pengertian Prosedur Kerja}

Efektivitas suatu pekerjaan harus dilandasi dengan prosedur kerja yang bagus. Menurut Sarwono (2011:192) "Prosedur kerja adalah suatu rangkaian dari tata kerja yang saling berhubungan satu dengan yang lain dimana terlihat adanya suatu urutan tahap demi tahap dan jalan yang harus ditempuh dalam rangka menyelesaikan suatu bidang tugas". Selanjutnya Mathir (2012:99) mengemukakan "Prosedur kerja merupakan suatu langkah-langkah kerja atau cara dalam pelaksanaan suatu tugas atau pekerjaan dengan mengingat segi-segi tujuan, peralatan, fasilitas, tenaga kerja, waktu, ruang dan biaya yang tersedia seefisien mungkin".

$$
\text { Sedangkan Dessler }
$$
menyatakan "Prosedur kerja adalah system kerja atau rangkaian antara tata kerja dan prosedur kerja yang dapat membentuk suatu kebulatan pola tertentu dalam rangka pelaksanaan suatu bidang pekerjaan".
Dari pernyataan di atas dapat dijelaskan bahwa prosedur kerja merupakan sebagai pola kerja yang dapat menjabarkan tujuan, sasaran, program kerja, fungsi-fungsi dan kebijaksanaan dalam kegiatan pelaksanaan yang nyata. Dapat juga sebagai standardisasi dan pengendalian kerja setepat-tepatnya dan sebagai pedoman kerja bagi para pelaksana atau semua pihak yang berkepentingan.

\section{Pengertian Fasilitas}

Menurut Sarwono (2011:94) "Fasilitas adalah sarana yang dapat digunakan untuk tujuan-tujuan tertentu guna mencapai suatu tujuan yang telah ditetapkan". Menurut Lupiyaodi (2011:150) "Fasilitas adalah sarana untuk melancarkan dan memudahkan pelaksanaan fungsi. Fasilitas merupakan komponen individual dari penawaran yang mudah ditumbuhkan atau dikurangi tanpa mengubah kualitas dan model jasa. Fasilitas juga merupakan alat untuk membedakan program lembaga pendidikan yang satu dari pesaing lainnya".

Menurut Daryanto (2010:91) "Fasilitas adalah sarana pendukung dalam aktivitas perusahaan berbentuk fisik, dan digunakan dalam kegiatan normal perusahaan, memiliki jangka waktu kegunaan yang relative permanen dan memberikan manfaat untuk masa yang akan datang". Fasilitas kerja sangatlah penting bagi perusahaan, karena dapat menunjang kinerja karyawan, seperti dalam penyelesaian pekerjaan.

\section{Pengertian Fasilitas Kerja}

Menurut Bari (2012:91) "Fasilitas kerja adalah sebagai sarana yang diberikan perusahaan untuk mendukung jalannya nada perusahaan dalam mencapai tujuan yang ditetapkan oleh pemegang kendali”. Sedangkan menurut Koyong (2011:11) "Fasilitas kerja adalah suatu bentuk pelayanan perusahaan terhadap karyawan 
agar menunjang kinerja dalam memenuhi kebutuhan karyawan, sehingga dapat meningkatkan produktifitas kerja karyawan". Fasilitas kerja yang memadai tentu saja akan berdampak positif pada proses kerja dalam perusahaan tersebut. Menurut Sarwono (2011:99) "Fasilitas kerja yang dimaksud dapat berupa lokasi, gedung, alat, benda, perlengkapan, maupun ruangan untuk bekerja.

\section{Pengertian Efektivitas}

Menurut Dessler (2008:110)

"Efektivitas menunjukkan keberhasilan dari segi tercapai tidaknya sasaran yang telah ditetapkan. Jika hasil kegiatan semakin mendekati sasaran berarti makin tinggi efektivitasnya". Sarwoto (2010:126) mengistilahkan efektivitas dengan "Berhasil guna yaitu pelayanan yang baik, corak dan mutunya benar-benar sesuai kebutuhan dalam pencapaian tujuan organisasi”. Menurut para ahli lainnya yaitu Mahmudi (2010:143) mengemukakan bahwa "Efektivitas adalah sejauh mana unit yang dikeluarkan mampu mencapai tujuan yang ditetapkan. Efektivitas digunakan untuk mengukur hubungan antara hasil pungutan suatu pajak dengan tujuan yang telah ditetapkan".

\section{Pengertian Efektivitas Kerja}

$$
\text { Menurut Siagian }
$$

"Efektivitas kerja merupakan suatu keadaan tercapainya tujuan yang diharapkan atau dikehendaki melalui penyelesaian pekerjaan sesuai dengan rencana yang telah ditentukan". Efektivitas merupakan pemanfaatan sumberdaya, sarana dan prasarana dalam jumlah tertentu yang secara sadar ditetapkan sebelumnya untuk menghasilkan sejumlah barang atas jasa kegiatan yang dijalankan.

$$
\text { Menurut Widjaya (2009:32) }
$$

mengemukakan: "Efektivitas kerja adalah hasil membuat keputusan yang mengarahkan melakukan sesuatu dengan benar, yang membantu memenuhi misi suatu perusahaan atau pencapaian tujuan". Selanjutnya Wesha (2010:148) mengatakan: "Efektivitas kerja adalah gambaran atau kemampuan berhasilnya suatu kerja yang dilakukan oleh manusia untuk memberikan guna yang diharapakan untuk melihat efektivitas kerja. Pada umumnya dipakai empat macam pertimbangan yaitu: Pertimbangan Ekonomi, Pertimbangan Fisiologi, Pertimbangan Psikologi dan Pertimbangan Sosial"

\section{Metode Penelitian \\ Ruang Lingkup Penelitian}

Penelitian ini dibatasi pada pengaruh prosedur kerja dan fasilitas kerja terhadap efektivitas kerja pegawai pada Dinas Sosial, Pemberdayaan Perempuan dan Perlindungan Anak Kabupaten Pidie Jaya

\section{Lokasi dan Objek Penelitian}

Penelitian ini dilakukan pada Dinas Sosial, Pemberdayaan Perempuan dan Perlindungan Anak Kabupaten Pidie Jaya. Alamat: Jln. Iskandar Muda, No. 01 Kota Meureudu - Kecamatan Meureudu, Kabupaten Pidie Jaya.

\section{Populasi dan Sampel \\ Populasi}

Populasi adalah totalitas dari semua objek atau semua individu yang memiliki karakteristik tertentu dan lingkup yang akan diteliti, populasi dalam penelitian ini adalah pegawai pada Dinas Sosial, Pemberdayaan Perempuan dan Perlindungan Anak Kabupaten Pidie Jaya yaitu sejumlah 32 orang pegawai.

\section{Sampel}

Menurut Arikunto (2011:116) "Penentuan pengambilan sampel sebagai berikut: Apabila kurang dari 100 lebih baik diambil semua hingga penelitiannya merupakan penelitian populasi. Jika jumlah populasinya besar dapat diambil antara 10$15 \%$ atau $20-30 \%$ ataupun lebih tergantung 
dari kesanggupan sipeneliti. Mengingat populasi dalam penelitian ini di bawah 100 , maka semuanya dilibatkan dalam sampel. Dengan demikian sampel dalam penelitian ini sebanyak 32 orang pegawai.

\section{Tekhnik Pengumpulan Data}

a. Observasi, yaitu langsung datang kelokasi penelitian untuk mendapatkan data awal penelitian.

b. Kuesioner, yaitu pengumpulan data yang dilakukan oleh penulis dengan cara menyebarkan daftar pernyataan yang telah di format khusus kepada responden yang sifatnya tertutup, yang pilihan jawabannya dengan menggunakan skala likert (1-5).

c. Wawancara, yaitu pengumpulan data yang dilakukan oleh penulis dengan cara melakukan tanyajawab secara langsung dengan pihak-pihak yang bersangkutan guna mendapatkan data dan informasi untuk mendukung penelitian ini.

d. Studi pustaka, yaitu pengumpulan data yang dilakukan oleh penulis dengan mengumpulkan data yang bersumber dari literatur-literatur, bahan kuliah, dan hasil penelitian lainnya yang ada hubungannya dengan objek penelitian.

\section{Skala Pengukuran}

Untuk memperoleh data penelitian penulis melalui penyebaran kuisioner dalam bentuk kualitatif dikomposisikan terlebih dahulu agar menjadi data kuantitatif. Adapun nilai kuantitatif yang dikomposisikan dilakukan dengan menggunakan skala Likert dan untuk satu pilihan dinilai (Score) dengan jarak interval 1. Nilai tersebutberkisar 1-5 seperti yang terlihat pada table dibawah ini:.

Tabel 3.2. AlternatifJawabanResponden

\begin{tabular}{|c|c|c|}
\hline Alternatif Jawaban & Katagori & Score Nilai \\
\hline Sangat Setuju & SS & 5 \\
\hline Setuju & S & 4 \\
\hline
\end{tabular}

\begin{tabular}{|c|c|c|}
\hline Kurang Setuju & KS & 3 \\
\hline Tidak Setuju & TS & 2 \\
\hline $\begin{array}{c}\text { Sangat Tidak } \\
\text { Setuju }\end{array}$ & STS & 1 \\
\hline
\end{tabular}

Sumber: Supranto (2011:105)

\section{Peralatan Analisis Data}

Metode analisis data yang digunakan dalam penelitian ini adalah Regresi Berganda yang diolah melalui computer dengan menggunakan program SPSS. Regresi linear berganda dapat dirumuskan secara berikut (Sugiyono, 2009:21) :

$$
\mathbf{Y}=\mathbf{a}+\mathbf{b}_{1} \mathbf{X}_{1}+\mathbf{b}_{2} \mathbf{X}_{2}+\mathbf{e}
$$

Dimana: $\mathrm{Y}=$ Efektivitas kerja

$$
\begin{aligned}
& \mathrm{a}=\text { Nilai Intercept (Konstanta) } \\
& \mathrm{b}_{1}=\text { Koefisien Motivasi } \\
& \mathrm{b}_{2}=\text { Koefisien PengalamanKerja } \\
& \mathrm{X}_{1}=\text { Variabel Prosedurkerja } \\
& \mathrm{X}_{2}=\text { Variabel Fasilitaskerja } \\
& \mathrm{e}=\text { standar error }
\end{aligned}
$$

\section{Hasil Penelitian Dan Pembahasan Uji Reliabilitas}

Pengujian reliabilatas menurut Simamora (2009:177) adalah tingkat kehandalan kuesioner yang apabila diujicobakan secara berulang-ulang kepada kelompok yang sama akan menghasilkan data yang sama. Cronbach alpha menerjemahkan korelasi antara skala yang dirancang dengan seluruh skala yang yang diukur dan juga dapat mengukur objek yang sama. Tingkat koefisien yang dikatakan handal adalah 0,60 , sedangkan reliabilitas di bawah tersebut dianggap kurang reliabel. (Sugiyono 2012: 109).

Tabel 4.3. Hasil Pengujian Reliabilitas

\begin{tabular}{|l|l|c|c|c|}
\hline \multicolumn{2}{|c|}{ No. dan variable } & $\begin{array}{c}\text { Jumlah } \\
\text { Variabe } \\
1\end{array}$ & $\begin{array}{c}\text { Nilai } \\
\text { Alpha }\end{array}$ & $\begin{array}{c}\text { Keterang } \\
\text { an }\end{array}$ \\
\hline 1 & $\begin{array}{l}\text { Prosedur } \\
\text { Kerja(X1) }\end{array}$ & 5 & .629 & Handal \\
\hline 2 & $\begin{array}{l}\text { Fasilitas } \\
\text { Kerja(X2) }\end{array}$ & 5 & .730 & Handal \\
\hline
\end{tabular}


Jurnal Sosial Humaniora Sigli (JSH)

p ISSN : 2615-3688

$e$ ISSN : 2716-0270

http://journal.unigha.ac.id/index.php/JSH

\begin{tabular}{|l|l|l|l|l|}
\hline 3 & $\begin{array}{l}\text { Efektivitas } \\
\text { Kerja } \\
\text { Pegawai(Y) }\end{array}$ & 5 & .607 & Handal \\
\hline
\end{tabular}

Sumber: Hasil Penelitian diolah (2019)

Dari uji di atas dapat dilihat bahwa, apabila alpha untuk masing-masing variable yaitu Prosedur Kerja(X1) dengan nilai alpha 0,629 persen, variable Fasilitas Kerja (X2) nilai alpha 0,730 persen, dan Efektivitas Kerja Pegawai (Y) di peroleh alpha 0,607 persen. Maka dapat dijelaskan bahwa pengukuran reliabilitas terhadap variable penelitian menunjukkan bahwa pengukuran keandalan memenuhi salah satu persyaratan baik, karena nilai alpha melebihi $60 \%$.

\section{Uji Validitas}

Uji Validitas dilakukan untuk mengatahui ketepatan data yang diperoleh dari lapangan sesuai dengan kenyataan atau harapan. Seluruh pernyataan dinyatakan valid dengan membandingkan r-hitung dengan r-tabel Product moment. Apabila rhitung lebih besar dari r-tabel' maka item pertanyaan dalam variabel valid. Sebaliknya jika r-hitung lebih kecil dari pada r-tabel, maka item pertanyaan dalam variabel tersebut tidak valid. Berdasarkan analisis yang telah dilakukan, maka hasil pengujian validitas dapat ditunjukkan sebagai berikut:

Tabel 4.2. Hasil Uji Validitas

\begin{tabular}{|c|c|c|c|c|}
\hline $\begin{array}{c}\text { Item } \\
\text { Pertanyaa } \\
\text { n } \\
\text { Kuesioner }\end{array}$ & $\begin{array}{c}\text { Varia } \\
\text { bel }\end{array}$ & $\begin{array}{c}\text { Koefisi } \\
\text { en } \\
\text { Korelas } \\
\text { i }\end{array}$ & $\begin{array}{c}\text { Nilai } \\
\text { Kritis } \\
5 \% \\
\mathrm{~N}=32\end{array}$ & $\begin{array}{c}\text { Keterang } \\
\text { an }\end{array}$ \\
\hline X1.1 & \multirow{5}{*}{$\mathrm{X} 1$} & .682 & 0,296 & Valid \\
\hline $\mathrm{X} 1.2$ & & .561 & 0,296 & Valid \\
\hline $\mathrm{X} 1.3$ & & .682 & 0,296 & Valid \\
\hline $\mathrm{X} 1.4$ & & .605 & 0,296 & Valid \\
\hline X1.5 & & .646 & 0,296 & Valid \\
\hline $\mathrm{X} 2.1$ & \multirow{5}{*}{$\mathrm{X} 2$} & .634 & 0,296 & Valid \\
\hline $\mathrm{X} 2.2$ & & .808 & 0,296 & Valid \\
\hline $\mathrm{X} 2.3$ & & .659 & 0,296 & Valid \\
\hline $\mathrm{X} 2.4$ & & .752 & 0,296 & Valid \\
\hline $\mathrm{X} 2.5$ & & .621 & 0,296 & Valid \\
\hline Y1 & \multirow[b]{3}{*}{ Y } & .523 & 0,296 & Valid \\
\hline Y2 & & .561 & 0,296 & Valid \\
\hline Y3 & & .563 & 0,296 & Valid \\
\hline
\end{tabular}

\begin{tabular}{|l|l|l|l|l|}
\hline Y4 & \multirow{4}{*}{} & .808 & 0,296 & Valid \\
\cline { 3 - 5 } & & .658 & 0,296 & Valid \\
\hline
\end{tabular}

Sumber: Hasil Penelitian diolah (2019)

Berdasarkan Tabel 4.2. di atas dapat dijelaskan bahwa semua variabel yang digunakan dalam penelitian ini dinyatakan valid, karena mempunyai koefisien korelasi di atas nilai kritis korelasi product moment yaitu sebesar 0,296, dan ketiga variable tersebut di atas dalam penelitian ini dapat digunakan untuk proses analisis data selanjutnya.

\section{Uji Normalitas}

Pengujian ini digunakan untuk menguji apakah data variabel dependen, variabel independen, keduanya mempunyai distribusi normal atau tidak. Analisis terhadap normalitas data dapat dilihat dengan melihat grafik normal probability plot yang membandingkan distribusi kumulatif data sesungguhnya dengan distribusi kumulatif data normal. Jika data menyebar digaris diagonal dan mengikuti arah garis diagonal, maka model regresi memenuhi asumsi normalitas. Hasil pengolahan data memperlihatkan normal probability plot seperti data di bawah ini:

\section{GAMBAR 4.1 NORMAL P-P Plot}

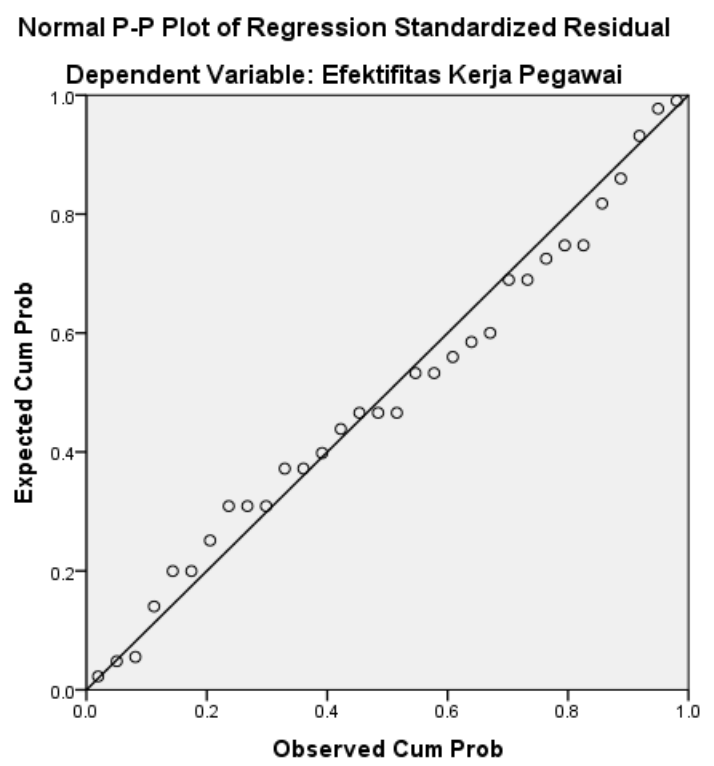




\section{Uji Multikolinearitas}

Untuk mengetahui ada atau tidaknya gejala multikolonieritas dilihat dari nilaitolerance dan VIF, jika nilai tolerance di atas 0,1 dan nilai VIF kurang 10, maka tidak adanya gejala multikolonearitas atau dengan bahasa lain tidak adanya ganguan nilai kritis yang dapat mempengaruhi nilai dari masing-masing variabel independen terhadap variabel dependen, untuk lebih jelas maka dapat dilihat padatabel4.8 sebagai berikut:

Tabel 4.4. Nilai VIF Variabel Bebas

\begin{tabular}{|c|c|c|c|c|}
\hline No & Variabel & $\begin{array}{c}\text { Toler } \\
\text { ance }\end{array}$ & VIF & Keterangan \\
\hline 1 & $\begin{array}{c}\text { Prosedur } \\
\text { Kerja(X1) }\end{array}$ & 0.380 & 2.632 & $\begin{array}{c}\text { Non } \\
\text { Multikolinear } \\
\text { itas }\end{array}$ \\
\hline 2 & $\begin{array}{c}\text { Fasilitas } \\
\text { Kerja(X2) }\end{array}$ & 0.380 & 2.632 & $\begin{array}{c}\text { Non } \\
\text { Multikolinear } \\
\text { itas }\end{array}$ \\
\hline
\end{tabular}

Sumber : Data primer, diolah, (2019)

Berdasarkan Tabel 4.4.dapat diketahui bahwa setiap variable memiliki nilai tolerance tidak kurang dari 0,10 dan nilai Variance Inflation Fackor (VIF) tidak lebih dari 10. Analisis ini menunjukkan bahwa tidak ada gejala multikolinearitas terhadap variable penelitian sehingga layak untuk digunakan untuk pengujian data untuk selanjutnya.

\section{Uji Hesterokedestisitas}

Deteksi ada tidaknya

heteroskedastisitas dapat dilakukan Jika ada pola tertentu, seperti titik-titik yang ada membentuk pola tetentu yang teratur (bergelombang, melebar kemudian menyempit), maka mengidentifikasikan telah terjadi heteroskedastisitas. Jika tidak ada pola yang jelas, serta titik-titik menyebar diatas dan dibawah angka 0 pada sumbu Y maka tidak terjadi heteroskedastisitas. Hasil pengolahan data menunjukkan grafik scatterplot seperti terlihat pada gambar berikut ini:

\section{Gambar 4.2. Uji Heteroskedastisitas}

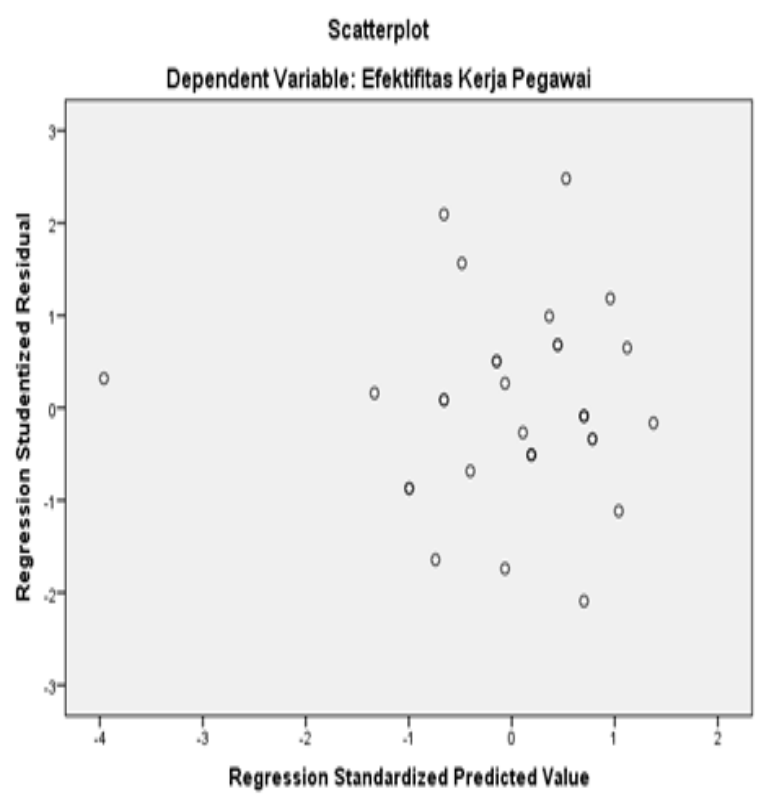

Dari gambar 4.2. di atas dapat dilihat jika ada titik membentuk pola tertentu yang teratur seperti bergelombang, melebar, kemudian menyempit maka telah terjadi heteroskedastisitas. Jika titik-titik menyebar diatas dan di bawah angka 0 pada sumbu $Y$ tanpa membentuk pola tertentu maka tidak terjadi heteroskedastisitas. Sebagaimana terlihat dilampiran maka grafik scatterplot tidak memiliki pola tertentu yang teratur (bergelombang, melebar kemudian menyempit), dengan demikian dapat diartikan tidak terjadi gelaja heteroskedastisitas

\section{Hasil Regresi Linear Berganda}

Untuk mengetahui pengaruh penempatan kerja dan lingkungan kerja terhadap semangat kerja, makadigunakan metode regresi linier berganda. Hal ini ditunjukan oleh nilai koefesien regresi masing-masing variabel seperti terlihat dalam bagian output SPSS di bawah ini: 
Jurnal Sosial Humaniora Sigli (JSH)

p ISSN : 2615-3688

$e$ ISSN : 2716-0270

http://journal.unigha.ac.id/index.php/JSH

Tabel 4.5. Hasil Regression

Coefficients $^{\mathrm{a}}$

\begin{tabular}{|c|c|c|c|c|c|c|c|}
\hline \multirow[t]{2}{*}{ Model } & \multicolumn{2}{|c|}{$\begin{array}{c}\text { Unstandardiz } \\
\text { ed } \\
\text { Coefficients }\end{array}$} & \multirow{2}{*}{\begin{tabular}{|c|} 
Stand \\
ardiz \\
ed \\
Coeff \\
icient \\
$\mathrm{s}$ \\
Beta
\end{tabular}} & \multirow[t]{2}{*}{$\mathrm{t}$} & \multirow[t]{2}{*}{ Sig. } & \multicolumn{2}{|c|}{$\begin{array}{c}\text { Collinearity } \\
\text { Statistics }\end{array}$} \\
\hline & B & \begin{tabular}{|l} 
Std. \\
Error
\end{tabular} & & & & $\begin{array}{l}\text { Toler } \\
\text { ance }\end{array}$ & VIF \\
\hline $\begin{array}{l}1 \text { (Const } \\
\text { ant) }\end{array}$ & 3.267 & $\begin{array}{l}.99 \\
8\end{array}$ & & $\begin{array}{l}3.2 \\
73\end{array}$ & $\begin{array}{c}.00 \\
3\end{array}$ & & \\
\hline $\begin{array}{l}\text { Prosed } \\
\text { ur } \\
\text { kerja }\end{array}$ & .518 & $\begin{array}{c}.09 \\
2\end{array}$ & $\begin{array}{l}.52 \\
7\end{array}$ & $\begin{array}{l}5.6 \\
06\end{array}$ & $\begin{array}{c}.00 \\
0\end{array}$ & $\begin{array}{c}.38 \\
0\end{array}$ & $\begin{array}{l}2.6 \\
32\end{array}$ \\
\hline $\begin{array}{l}\text { Fasilita } \\
\text { s kerja }\end{array}$ & .392 & $\begin{array}{l}.07 \\
7\end{array}$ & $\begin{array}{c}.47 \\
8\end{array}$ & $\begin{array}{l}5.0 \\
80\end{array}$ & $\begin{array}{c}.00 \\
0\end{array}$ & $\begin{array}{c}.38 \\
0\end{array}$ & $\begin{array}{l}2.6 \\
32\end{array}$ \\
\hline
\end{tabular}

Sumber : Hasil Penelitian, 2019 (Data Diolah)

Dari data-data pada tabel di atas diperoleh persamaan regresi sebagai berikut: $\mathrm{Y}=3.257+.518 \mathrm{X}_{1}+.392 \mathrm{X}_{2}$. Konstanta sebesar 3.267 artinya bahwa, pada keadaan variabel X1 (Prosedur Kerja), apabila X1 naik 3,257\% maka Y (Efektivitas Kerja Pegawai) meningkat sebesar $0,518 \%$ sementara variabel X2 diasumsikan tetap. Selanjutnya apabila X2 (Fasilitas Kerja) meningkat sebesar 3,257\% saja, maka Y (Efektivitas Kerja Pegawai) meningkat sebesar $0,392 \%$ sementara variabel X1 diasumsikan tetap.

Selanjutnya untuk mengetahui hubungan dan pengaruh masing-masing variable dapat dilihat tabel 4.6.berikut ini.

Tabel 4.6. Collinearity Statistics

\begin{tabular}{|c|c|c|c|c|c|c|}
\hline & & & odel S & ammary & & \\
\hline \multirow[b]{2}{*}{ Model } & \multirow[b]{2}{*}{$\mathrm{R}$} & \multirow{2}{*}{$\begin{array}{c}\mathrm{R} \\
\text { Squa } \\
\text { re }\end{array}$} & \multirow{2}{*}{$\begin{array}{l}\text { Adju } \\
\text { sted } \\
\text { R } \\
\text { Squa } \\
\text { re }\end{array}$} & \multirow{2}{*}{$\begin{array}{l}\text { Std. } \\
\text { Error } \\
\text { of the } \\
\text { Estima } \\
\text { te }\end{array}$} & \multicolumn{2}{|c|}{$\begin{array}{l}\text { Durbin- } \\
\text { Watson }\end{array}$} \\
\hline & & & & & \begin{tabular}{|c} 
Sig. \\
F \\
Chan \\
ge
\end{tabular} & \\
\hline 1 & $.950^{\mathrm{a}}$ & $\begin{array}{c}90 \\
3\end{array}$ & $\begin{array}{c}.89 \\
6\end{array}$ & .522 & ,003 & 2.380 \\
\hline
\end{tabular}

Sumber : Hasil Penelitian, 2019 (Data Diolah)
Dari tabel 4.6. di atas dapat dilihat bahwa, nilai koefisien korelasi (R) bertujuan untuk mengetahui hubungan antara variable independen dengan variable dependen, Nilai koefisien kolerasi diperoleh sebesar 0,950 atau $95 \%$ dapat memberikan pengertian ada hubungan antara factor prosedur kerja dan fasilitas kerja dengan efektivitas kerja pegawai. Semakin tingginya nilai koefisien korelasi yang diperoleh maka semakin erat pula hubungan antara variable independen dengan variable dependen. Dengan demikian dapat dijelaskan variable prosedur kerja dan fasilitas kerja mempunyai hubungan sebesar $95 \%$ terhadap efektivitas kerja pegawai.

Sedangkan nilai koefisien diterminasi $\left(\mathrm{R}^{2}\right)$ adalah bertujuan untuk mengetahui pengaruh antara prosedur kerja dan fasilitas kerja dengan efektivitas kerja pegawai. Nilai koefisien diterminasi diperoleh sebesar 0,903 atau $90,3 \%$ dapat memberikan pengertian ada pengaruh yang signifikan antara factor prosedur kerja dan fasilitas kerja dengan efektivitas kerja pegawai. Dengan demikian dapat dijelaskan bahwa pengaruh prosedur kerja dan fasilitas kerja sebesar $90.3 \%$ berpengaruh secara siginifikan (sig 0,000) terhadap efektivitas kerja pegawai, sedangkan selebihnya 9,7\% dipengaruhi oleh persamaan lain di luar penelitian ini

\section{Pembuktian Hipotesis \\ Pembuktian Secara Simultan (Uji F)}

Uji $F$ bertujuan untuk menguji hipotesis secara serempak atau secara simultan. Dalam penelitian ini diperoleh Fhitung sebesar 134.345 danF-tabel $_{\text {pada tingkat }}$ kepercayaan $05 \%$ diperoleh sebesar 3,23 (tabel F). Berdasarkan hasil uji $\mathrm{F}$ tersebut maka keputusan penelitian ini diperoleh Fhitung lebih besar dariF-tabel. Dengan demikian secara simultan, hasil penelitian ini dapat diambil keputusan dengan menerima hipotesis Ha dan Menolak hipotsis Ho. Artinya ada pengaruh yang signifikan antara prosedur kerja dan fasilitas kerja 
dengan efektivitas kerja pegawai, dengan demikian keputusan penelitian ini adalah menerima hipotesis Ha. Dapat diambil keputusan bahwa, uji-T dan Uji-F diperoleh nilai lebih besar dari T-tabel dan F-tabel, sehingga dalam penelitian ini diterima hipotesis Ha dan menolak hipotesis Ho.

\section{Pembuktian Secara Parsial (Uji t)}

Sebagaimana hipotesis yang telah ditetapkan bahwa ada pengaruh antara prosedur kerja dan fasilitas kerja terhadap efektivitas kerja pegawai. Pembuktian hipotesis dengan Uji-T secara partial dan Uji-F secara simultan yaitu:

Hasil pengujian dapat dilihat untuk variabel prosedur kerja (X1) diperoleh nilai $\mathrm{T}_{\text {-hitung }}$ sebesar 5.606 dan $\mathrm{T}$-tabel pada tingkat kepercayaan $05 \%$ sebesar 1,669. Untuk variabel fasilitas kerja (X2) diperoleh nilai $\mathrm{T}_{\text {-hitung }}$ sebesar 5.080 dan $\mathrm{T}$-tabel pada tingkat kepercayaan $05 \%$ sebesar 1,669. Untuk variabel efektivitas kerja pegawai (Y) diperoleh nilai $\mathrm{T}_{\text {-hitung }}$ sebesar 3.273 dan $\mathrm{T}$ tabel pada tingkat kepercayaan $05 \%$ sebesar 1,669. Dengan kata lain $\mathrm{T}$-hitung $>\mathrm{T}$-tabel. Secara partial berarti ada pengaruh yang signifikan antara prosedur kerja dan fasilitas kerja dengan efektivitas kerja pegawai, dengan demikian keputusan penelitian ini adalah menerima hipotesis Ha.

\section{Kesimpulan}

1. Untuk meningkatkan efektivitas kerja pegawai, maka suatu organisasi perlu menetapkan prosedur kerja yang lebih baik dan jelas serta menyediakan fasilitas kerja yang mencukupi, karena variable tersebut berpengaruh terhadap efektivitas kerja pegawai.

2. Nilai koefisien kolerasi diperoleh sebesar $95 \%$ dapat memberikan pengertian ada hubungan antara factor prosedur kerja dan fasilitas kerja dengan efektivitas kerja pegawai. Semakin tingginya nilai koefisien korelasi yang diperoleh maka semakin erat pula hubungan antara variable independen dengan variable dependen.

3. Sedangkan nilai koefisien diterminasi $\left(\mathrm{R}^{2}\right)$ adalah bertujuan untuk mengetahui pengaruh antara prosedur kerja dan fasilitas kerja dengan efektivitas kerja pegawai. Nilai koefisien diterminasi diperoleh sebesar 90,3\% dapat memberikan pengertian ada pengaruh yang signifikan antara factor prosedur kerja dan fasilitas kerja dengan efektivitas kerja pegawai. Dengan demikian dapat dijelaskan bahwa pengaruh prosedur kerja dan fasilitas kerja sebesar $90.3 \%$ berpengaruh secara siginifikan (sig 0,000) terhadap efektivitas kerja pegawai, sedangkan selebihnya $9,7 \%$ dipengaruhi oleh persamaan lain di luar penelitian ini.

4. Ada pengaruh yang signifikan antara prosedur kerja dan fasilitas kerja dengan efektivitas kerja pegawai, dengan demikian keputusan penelitian ini adalah menerima hipotesis Ha. Dapat diambil keputusan bahwa, uji-T dan Uji-F diperoleh nilai lebih besar dari T-tabel dan F-tabel, sehingga dalam penelitian ini diterima hipotesis $\mathrm{Ha}$ dan menolak hipotesis Ho

\section{Daftar Pustaka}

Asri. 2012. Manajemen Sumber Daya Manusia Edisi Kedua. Bandung :CV.Alfabeta.

Fahmi, Irham. 2015.Manajemen Kinerja Tiori dan Aplikasi. Bandung : CV. Alfabeta.

Gitosudarmo. 2016. Manajemen Sumber Daya manusia. Bandung : CV. Alfabeta.

Hasibuan, Malayu, SP. 2013. Manajemen Sumber Daya Manusia Edisi Revisi. Jakarta: PT. Bumi Aksara 
Jurnal Sosial Humaniora Sigli (JSH)

p ISSN : 2615-3688

$e$ ISSN : 2716-0270

http://journal.unigha.ac.id/index.php/JSH

Ibrahim. 2016. Pengaruh motivasi dan gaji terhadap peningkatan kinerja karyawan pada PT. Bank BRI Cabang Sigli Kabupaten Pidie.

Sarjono, Haryadi\&Julianita, Winda. 2013. SPSS vs LISREL Sebuah Pengantar, Aplikasi untuk Riset. Jakarta : Selemba Empat.

Idrus. 2014. Pengaruh Disiplin dan Motivasi terhadap peningkatan Kinerja Pegawai Dinas Kesehatan Kabupaten Pidie.

Manulang. 2015. Manajemen Sumber Daya Manusia. Jakarta : BumiAksara.

Mangkunegara, Anwar Prabu. 2013. Manajemen Sumber Daya Manusia Perusahaan. Bandung : PT. Remaja Rosdakarya

Rosmini. 2014. Pengaruh Pelatihan dan Pengalaman Kerja Terhadap Kinerja Pegawai Dinas Perhubungan Kabupaten Pidie.

Robbins, Stephen, P. 2012. Organization Behavior $15^{\text {th }}$ Edition. Pearson Edition.

Siagian, Sodang, P. 2016. Manajemen Sumber Daya manusia. Jakarta : Bumi Aksara.

Sustrisno, Edy. 2016. Manajemen Sumber Daya Manusia. Jakarta : Prenadamedia Group.

Syahrum dan Salim. 2015. Metode Penelitian Kuantitatif. Jakarta : Cita pustaka Media.

Trijoko. 2013. Manajemen Sumber Daya Manusia. Jakarta : Bumi Aksara.

Yusuf, Burhanuddin, 2015. Manajemen Sumber Daya Manusia Dilembaga Keuangan Syariah. Jakarta : PT Raja Grafindo Persada. 